\title{
Curing Hepatitis C in Liver Transplant Recipients Is Associated with Changes in Immunosuppressant Use
}

\author{
Sammy Saab*1,2, Justin Rheem ${ }^{3}$, Melissa Jimenez ${ }^{1}$, Sherona Bau ${ }^{2}$, Gina Choi ${ }^{1,2}$, \\ Francisco Durazo ${ }^{1,2}$, Mohammed El Kabany ${ }^{1,2}$, Steven Han ${ }^{1,2}$, Alexander Farid ${ }^{1}$, \\ Naadir Jamal ${ }^{1}$, Jonathan Grotts ${ }^{1}$, David Elashoff ${ }^{1,4}$ and Ronald W. Busuttil ${ }^{2}$
}

${ }^{1}$ Departments of Medicine at the University of California at Los Angeles, Los Angeles, California, USA; ${ }^{2}$ Department of Surgery at the University of California at Los Angeles, Los Angeles, California, USA; ${ }^{3}$ Department of Medicine at Harbor-University of California at Los Angeles Medical Center, Torrance, California, USA; ${ }^{4}$ Department of Biostatistics at the University of California at Los Angeles, Los Angeles, California, USA

Abstract

Background and Aims: All-oral interferon-free antivirals are highly effective in treating recurrent hepatitis C (HCV) infection in liver transplant (LT) recipients. The aim of the study was to assess immunosuppression needs after achieving a sustained viral response (SVR). Methods: We compared immunosuppression needs before and after achieving a SVR in adult LT recipients treated for recurrent HCV infection with alloral direct acting agents. Results: We identified 52 liver LT treated recipients who achieved a SVR. The median (25th and 75 th percentile interquartile range [IQR]) age was 62 years $(57.75,65)$. Most recipients received tacrolimus (TAC) for their immunosuppressant regimen. After achieving SVR, there was no statistically significant difference in daily dose of TAC unadjusted per weight $(p>0.05)$. However, there was a statistically significant decrease in daily dose of TAC adjusted per weight, serum levels of TAC, and the product of glomerular filtration rate and TAC. No statistically significant differences in cyclosporine unadjusted/adjusted per weight daily dose or serum levels were noted. Conclusions: Immunosuppression needs were increased for those patients treated with TAC but not cyclosporine. LT recipients prescribed TAC require close monitoring after treatment completion to avoid potential risk of acute rejection.

(c) 2016 The Second Affiliated Hospital of Chongqing Medical University. Published by XIA \& HE Publishing Inc. All rights reserved.

Keywords: Liver transplantation; Immunosuppressant; Hepatitis C; Direct acting agents.

Abbreviations: ALT, alanine aminotransferase; AP, alkaline phosphatase; AST, aspartate Transaminase; BMI, body mass index; CKD-EPI, Chronic Kidney Disease Epidemiology Collaboration Formula; CSA, cyclosporine; GFR, glomerular filtration rate; HCV, Hepatitis C; HIV, human immunodeficiency virus; IQR, interquartile range; LT, liver transplant; MELD, Model for End-Stage Liver Disease; mTOR, mammalian target of rapamycin; SVR, sustained viral response; TAC tacrolimus; TDD, total daily dose; UCLA, University of California, Los Angeles Medical Center.

Received: 5 January 2016; Revised: 19 February 2016; Accepted: 24 February 2016

DOI: $10.14218 / \mathrm{JCTH} .2016 .00001$.

*Correspondence to: Sammy Saab, Pfleger Liver Institute, UCLA Medical Center, 200 Medical Plaza, Suite 214, Los Angeles, CA 90095, USA. Tel: +1-310-2066705, Fax: +1-310-206-4197, E-mail: SSaab@mednet.ucla.edu

\section{Introduction}

Liver transplantation (LT) is the definitive treatment for patients with advanced liver disease and hepatocellular carcinoma. ${ }^{1-3}$ Initial attempts at LT in the 1960 s were limited by graft failure from cellular rejection. ${ }^{4-6}$ Advances in immunosuppressive therapy have led to substantial improvement in patient and graft survival over the past several decades. ${ }^{7}$ However, the use of immunosuppressive therapy is also associated with long term complications, such as hypertension, diabetes, and renal insufficiency. ${ }^{8-13}$ The goal of immunosuppressive therapy is to maximize protection from rejection while minimizing the adverse effects by using the lowest dose possible. ${ }^{14}$

The most common indication for LT in the United States is hepatitis C. ${ }^{15}$ However, recurrent HCV infection is universal, and its progression to cirrhosis can lead to graft loss in a significant number of LT recipients. ${ }^{16-18}$ Successful treatment of recurrent hepatitis $\mathrm{C}$ virus $(\mathrm{HCV})$ infection in $\mathrm{LT}$ recipients can reduce the risk of subsequent $\mathrm{HCV}$-related complications and graft loss. ${ }^{14,17,19,20}$ The use of interferon to treat recurrent $\mathrm{HCV}$ was associated with concerns for graft loss because of the perceived enhanced immune modulating effects of interferon. ${ }^{21-23}$ Furthermore, graft failures were found to occur after viral suppression was achieved. ${ }^{21}$

The introduction of all-oral interferon-free antiviral therapy has revolutionized the treatment of HCV infection. These treatments are safe and highly effective in LT recipients with recurrent $\mathrm{HCV}$ infection, thus broadening the group of patients eligible for treatment. ${ }^{24-26}$ A direct consequence of avoiding interferon in the treatment of recurrent $\mathrm{HCV}$ is the increased number of recipients that would be eligible for the interferonfree therapy. However, a possible unexpected consequence of achieving viral suppression may be improved metabolism of immunosuppressant medications, aside from direct drugdrug interactions. For instance, the results of two recent studies of direct acting agents highlight changes in immunosuppressant dosing after antiviral therapy was completed. ${ }^{26,27}$ Calcineurin inhibitors are all metabolized by the liver (cytochrome P-450 3A4 system) and increased performance of hepatic metabolism function highly influences the bioavailability of these medications. ${ }^{28}$ With improved liver function after HCV treatment in LT recipients, patients' needs for immunosuppression may change. 
Saab S. et al: Curing Hepatitis $C$ affects post liver transplant immunosuppressant use

The hypothesis of this study is that LT recipients who achieve a sustained viral response (SVR) will require greater amounts of immunosuppression. Understanding this phenomenon will help to tailor strategies that will protect LT recipients from potential graft rejection after they are cured of HCV.

\section{Methods}

We performed a retrospective cohort study of all adult (age $>18$ years) LT recipients who achieved SVR after being treated with all-oral HCV antiviral therapy for recurrent HCV infection at the University of California, Los Angeles Medical Center (UCLA) between October 2011 and October 2014. A SVR was defined as an undetectable HCV RNA 12 weeks after treatment completion. Exclusion criteria included active infection, biliary obstruction, and allograft rejection on biopsy within 6 months of starting antiviral therapy.

This study was approved by the UCLA Institutional Review Board. Patient consent was not required. Data were obtained by medical chart review and retrieved by the UCLA Liver Transplant database. Demographic data (age, gender, and race/ethnicity), history of LT, history of previous HCV therapy, nonliver related medical history (active cardiopulmonary disease, hemodialysis, stroke, nonliver malignancy, and diabetes), co-existent liver disease (nonalcoholic fatty liver disease, hepatitis $B$, and autoimmune hepatitis), and stage of fibrosis, categorized as Mild (stage 0-2) and Moderate to Severe (stage 3-4), were recorded. Fibrosis was defined by liver biopsy, laboratory testing, and radiological imaging. Hematologic, biochemical data, immunosuppressant levels, and HCV RNA levels were collected prior to initiation of antiviral therapy and after achieving a SVR.

\section{Immunosuppressive needs}

We ascertained immunosuppressant needs through a variety of methods: 1) total daily dose of the immunosuppressant, 2 ) the dose of immunosuppressant per the recipient body weight ( $\mathrm{kg}), 3$ ) product of immunosuppressant and glomerular filtration rate (GFR) (Chronic Kidney Disease Epidemiology Collaboration Formula, CKD-EPI, $\mathrm{mL} / \mathrm{min} / 1.73 \mathrm{~m}^{2}$ ). The last method was chosen since it is our custom to tailor immunosuppressant dose to GFR to avoid renal toxicity. We compared laboratory values and computations for 3 months before starting HCV therapy and 3 months after therapy was completed.

\section{Statistics}

Data are presented as medians with $25^{\text {th }}$ and $75^{\text {th }}$ percentile interquartile range (IQR) for continuous variables and number within group with percent of group for discrete variables. The within patient differences in labs and medication regiments were compared before and after treatment using the two-sided Wilcoxon Rank Sum test. A multivariable linear regression model with percent change in immunosuppressant serum level as the dependent variable and percent change in alanine aminotransferase (ALT) and weight-adjusted, total daily dose as the independent variables was used to assess changes in serum level with respect to medication and liver function. $p<0.05$ was considered statistically significant. The R Statistical Computing Environment was used for data analysis (R Core Team 2015).

\section{Results}

The demographics of the study patient cohort are presented in Table 1 . Twenty-five $(48.1 \%)$ recipients had at least one nonhepatic comorbidity. Few patients had concomitant fatty liver, and no recipients were co-infected with hepatitis B or human immunodeficiency virus (HIV). Twenty percent of recipients had a diagnosis of hepatocellular carcinoma prior to LT. Most patients were infected with genotype $1(78.8 \%)$. The rest of patients were infected with genotypes 2,3 , and $4(5.8 \%, 11.5 \%$ and $3.8 \%$, respectively). Pretreatment lab results were available a median (IQR) of $5(3,7.25)$ months. The median (IQR) time from SVR12 to collection of three laboratory values was 5 months $(4,7.25)$.

Tacrolimus (TAC)-based immunosuppression was used in $75 \%$ of LT recipients. The median (IQR) total daily dose, weight-adjusted total daily dose, and serum TAC values were $2(1.5,4) \mathrm{mg}, 0.03(0.02,0.05) \mathrm{mg} / \mathrm{kg}$, and $8.1(6.57,9.1)$ $\mathrm{ng} / \mathrm{mL}$, respectively. Of the recipients treated with cyclosporine, the median (IQR) total daily dose, weight-adjusted total daily dose, and serum cyclosporine was 150 (133.33, 200) $\mathrm{mg}, 1.93(1.37,2.81) \mathrm{mg} / \mathrm{kg}$, and $112(79,128.67)$ $\mathrm{ng} / \mathrm{mL}$, respectively. Fifteen percent of recipients treated with TAC had moderate to severe fibrosis, and 39\% of recipients treated with cyclosporine had moderate to severe fibrosis. Most recipients were taking mycophenolate before and after achieving a SVR.

The median (IQR) aspartate aminotransferase (AST) and ALT before achieving a SVR were $58.83(40.66,80.92)$ and $62.66(43.67,88.42)$, respectively. There was a statistically significant improvement in all assessed liver associated tests in LT recipients who achieved SVR12 $(p<0.05)$ (Table 2 ). There was also a statistically significant improvement in platelet count $(p=0.005)$. Body mass index (BMI) increased with SVR12. The median (IQR) BMI was 26.8 (23.69, 29.78) before treatment initiation and 27.58 (23.94, 31.0) after SVR $(p=0.012)$. There was no change in renal function as measured by GFR after achieving SVR $(p=0.099)$.

Changes in immunosuppression need were assessed in multiple ways (Tables 3 and 4). Most recipients treated with TAC had a decrease in their weight adjusted total daily dose of TAC and TAC serum levels (Table 3 ). There was no statistically significant change in the unadjusted total dose of TAC ( $p=0.174)$, but there was an observed significant decrease in weight adjusted total dose of TAC $(p=0.001)$ and serum levels of TAC after achieving SVR ( $p$-value <0.001) (Table 4, Figure 1a). Moreover, the product of TAC serum level and GFR was significantly lower after SVR $(p<0.001)$. In contrast, there was no significant changes in unadjusted or adjusted total dose of cyclosporine, serum levels of cyclosporine, or the product of cyclosporine serum level and GFR $(p>0.05)$ (Table 4, Figure 1b). There was an observed interaction between serum change of immunosuppression levels and total daily dose immunosuppression with the percent change of median ALT values (Figure 2). In a multivariate analysis, there was an observed relationship between percent change in serum levels and percent change in weight-adjusted, total daily dose $(p=0.027)$, but not in percent change in median ALT values $(p=0.226)$. When restricting the population to only patients taking TAC, the relationship was significant between change in serum levels and weight-adjusted total daily dose $(p=0.014)$ and change in serum levels and change in median ALT values $(p=0.022)$. 
Saab S. et al: Curing Hepatitis $C$ affects post liver transplant immunosuppressant use

Table 1. Demographic and baseline values

\begin{tabular}{|c|c|c|c|}
\hline Variable & All & Tacrolimus & Cyclosporine \\
\hline Number of patients & 52 & 39 & 13 \\
\hline Age, median (interquartile range) & $62(58,65)$ & $62(58,65)$ & $60(55,63)$ \\
\hline \multicolumn{4}{|l|}{ Gender } \\
\hline Male (\%) & $42(80.77)$ & $31(79.49)$ & $11(84.62)$ \\
\hline \multicolumn{4}{|l|}{ Ethnicity } \\
\hline Hispanic (\%) & $18(34.62)$ & $12(30.77)$ & $6(46.15)$ \\
\hline Non-Hispanic White (\%) & $16(30.77)$ & $11(28.21)$ & $5(38.46)$ \\
\hline Other $(\%)$ & $18(34.62)$ & $16(41.03)$ & $2(15.38)$ \\
\hline Body Mass Index $\left(\mathrm{kg} / \mathrm{m}^{2}\right)$, median (interquartile range) & $\begin{array}{l}26.8(23.69, \\
29.78)\end{array}$ & $\begin{array}{l}25.73(23.23 \\
29.55)\end{array}$ & $28.59(25.58,30.94)$ \\
\hline $\begin{array}{l}\text { Months since liver transplant, median (interquartile } \\
\text { range) }\end{array}$ & $\begin{array}{l}32.9(13.78 \\
74.42)\end{array}$ & $\begin{array}{l}29.18(13.09 \\
60.82)\end{array}$ & $\begin{array}{l}59.24(39.63 \\
179.60)\end{array}$ \\
\hline \multicolumn{4}{|l|}{ Mycophenolate } \\
\hline Before Treatment & $36(69.23)$ & $29(74.36)$ & $7(53.85)$ \\
\hline After Treatment & $35(67.31)$ & $26(66.67)$ & $9(69.23)$ \\
\hline \multicolumn{4}{|l|}{ Sirolimus } \\
\hline Before Treatment & $1(1.92)$ & $0(0)$ & $1(7.69)$ \\
\hline After Treatment & $2(3.85)$ & $1(2.56)$ & $1(7.69)$ \\
\hline Hepatitis C Treatment Experienced (\%) & $23(44.2)$ & $14(35.9)$ & $9(69.2)$ \\
\hline \multicolumn{4}{|l|}{ Antiviral Therapy } \\
\hline Sofosbuir/Ribavirin (\%) & $31(59.6)$ & $23(59)$ & $8(61.5)$ \\
\hline Sofosbuir/Simeprevir (\%) & $21(40.4)$ & $16(41)$ & $5(38.5)$ \\
\hline \multicolumn{4}{|l|}{ Non-hepatic comorbidities } \\
\hline Cardiac disease (\%) & $5(9.6)$ & $5(12.8)$ & $0(0)$ \\
\hline Hemodialysis (\%) & $3(5.77)$ & $2(5.13)$ & $1(7.69)$ \\
\hline Cerebral vascular stroke (\%) & $1(1.92)$ & $1(2.56)$ & $0(0)$ \\
\hline Non-liver malignancy (\%) & $5(9.6)$ & $4(10.3)$ & $1(7.69)$ \\
\hline Diabetes (\%) & $17(32.69)$ & $13(33.33)$ & $4(30.77)$ \\
\hline Lymphoma (Non-PTLD) (\%) & $1(1.92)$ & $0(0)$ & $1(7.7)$ \\
\hline
\end{tabular}

\section{Discussion}

The results of our study demonstrate that LT recipients immunosuppression needs may increase after achieving a SVR. The goal of immunosuppression in LT is to minimize clinically significant side effects and to prevent rejection. ${ }^{28-32}$ Immunosuppression regimens are tailored based on multiple factors, including renal and hepatic function, and may require frequent adjustments by providers to tailor them to the individual patient. Therefore, the clinical implication of our study is that LT recipient's status post-recurrent HCV treatment may be at increased risk of rejection.

Our results are consistent with prior observations made by others. Kwo et al. found that eight out of 34 LT recipients required adjustments of their immunosuppressant shortly after completing their antiviral therapy. ${ }^{26}$ Although there is a significant drug-drug interaction between the 3D regimen, TAC, and cyclosporine, and the immunosuppressant trough levels were mostly stabilized several weeks after initiation of the $3 \mathrm{D}$ regimen, these observations were made after completing therapy. ${ }^{33}$ Likewise, Chartlon et al. described 25 of 229 LT recipients who required dose adjustments after completing a course of antiviral therapy, but the direction of the change was not characterized. ${ }^{27}$

We speculate that improvement in liver function with interferon-free therapy may explain the increased need for immunosuppression. In patients with recurrent HCV posttransplantation, treatment with interferon-free therapy resulted in early post-treatment liver function improvement, as evidenced by decreases in bilirubin and Model for EndStage Liver Disease (MELD) scores and increases in albumin. ${ }^{34,35}$ Improved metabolic function of the liver may explain our results. Calcineurin inhibitors, mammalian target of rapamycin (mTOR) inhibitors, and antimetabolites are metabolized by the liver (cytochrome P-450 3A4 system), and performance of hepatic metabolism function highly influences the bioavailability of these agents. ${ }^{28}$ An important finding of our study is the differential effect of curing HCV on 
Saab S. et al: Curing Hepatitis C affects post liver transplant immunosuppressant use

Table 2. Changes in clinical and laboratory parameters before and after achieving a sustained viral response. Data are presented as a median with interquartile range in parenthesis for continuous variables

\begin{tabular}{|c|c|c|c|c|}
\hline Parameter & Before & After & Within patient difference & P-value \\
\hline \multicolumn{5}{|l|}{ Clinical } \\
\hline BMI $\left(\mathrm{kg} / \mathrm{m}^{2}\right)$ & $26.8(23.685,29.777)$ & $27.58(23.94,31.003)$ & $0.46(-0.153,1.588)$ & 0.012 \\
\hline \multicolumn{5}{|l|}{ Laboratory } \\
\hline Hemoglobin $(\mathrm{g} / \mathrm{dL})$ & $12.84(11.047,14.803)$ & $13.435(11.793,14.72)$ & $0.48(-0.592,1.462)$ & 0.111 \\
\hline $\begin{array}{l}\text { Platelet Count } \\
\left(\times 10 E^{3} / \mu L\right)\end{array}$ & $\begin{array}{l}121.335(77.875 \\
147.92)\end{array}$ & $\begin{array}{l}136.835(104.082, \\
159.67)\end{array}$ & $11.835(-5.165,34.915)$ & 0.005 \\
\hline $\mathrm{SCL}(\mathrm{mg} / \mathrm{dL})$ & $1.13(0.908,1.355)$ & $1.115(0.918,1.36)$ & $0.03(-0.1,0.15)$ & 0.412 \\
\hline Albumin (g/dL) & $4.07(3.73,4.3)$ & $4.37(4.17,4.508)$ & $0.215(0.07,0.515)$ & $<0.001$ \\
\hline AST (U/L) & $58.83(40.665,80.918)$ & $24.665(18.67,30.415)$ & $-27.335(-54.165,-14.082)$ & $<0.001$ \\
\hline ALT (U/L) & $62.665(43.668,88.418)$ & $21.665(16,33.415)$ & $-34.835(-65.08,-15.668)$ & $<0.001$ \\
\hline $\begin{array}{l}\text { Biliburin, total } \\
\text { (mg/dL) }\end{array}$ & $0.95(0.73,1.178)$ & $0.7(0.53,0.948)$ & $-0.215(-0.4,-0.06)$ & $<0.001$ \\
\hline $\mathrm{AP}(\mathrm{U} / \mathrm{L})$ & $96.5(73.75,134.502)$ & $84.665(63.75,117.418)$ & $-14.835(-28.338,-0.077)$ & 0.001 \\
\hline $\begin{array}{l}\text { GFR } \\
\left(\mathrm{mL} / \mathrm{min} / 1.73 \mathrm{~m}^{2}\right)\end{array}$ & $65(53,80.498)$ & $62(48.502,78.33)$ & $-1.67(-8.33,3.25)$ & 0.099 \\
\hline
\end{tabular}

Abbreviations: $\mathrm{BMI}$, body mass index; SCL, creatinine; AST, aspartate aminotransferase; ALT, alanine aminotransferase; AP, alkaline phosphatase; GFR, glomerular filtration rate.

TAC and cyclosporine levels. One possible explanation could be that the serum concentration of cyclosporine is 15 -fold higher than that of TAC $(112 \mathrm{ng} / \mathrm{ml} \mathrm{vs} 8.1 \mathrm{ng} / \mathrm{ml}$, respectively) and that cyclosporine, but not TAC, has a pharmacokinetics inhibitory effect on hepatic CYP metabolic enzymes. ${ }^{36}$

In addition, restoration of host immune response by interferon-free therapy may also explain this phenomenon. In chronic hepatitis $\mathrm{C}$ infection, $\mathrm{HCV}$ renders the host's virusspecific CD8+ T cells dysfunctional and transient by several mechanisms, such as viral escape and T-cell exhaustion. ${ }^{37,38}$ Previously, interferon-based therapies failed to recover HCVspecific CD8+ T cell functions. ${ }^{39,40}$ However, in a recent study with IFN-free therapies (faldaprevir and deleobuvir), proliferative HCV-specific CD8+ T cells were rapidly restored in the majority of patients $(\mathrm{n} / \mathrm{N}=19 / 22,86.4 \%) .^{3}$ In contrast,
HCV-specific CD8+ T cells did not increase in patients with treatment failure. This finding suggests that adaptive immunity after successful HCV treatment is restored and may require immunosuppression adjustment to prevent graft rejection.

In addition, successful HCV therapy can lead to removal of the immunosuppressive effect from HCV itself. In a few LT recipients, immunosuppressive medication may not be required after sometime due to a phenomenon called "transplant tolerance." 29,41 Its mechanism is not completely understood, but the current hypothesis is that HCV infection induces immunoregulation and facilitates "transplant tolerance," leading to successful discontinuation of immunosuppression. ${ }^{41}$ In contrast, a successful eradication of the immunosuppressive effect of HCV may lead to a heightened

Table 3. Changes in immunosuppressant parameters

\begin{tabular}{llll}
\hline Variable & All $(\mathrm{n}=52)$ & $\begin{array}{l}\text { Tacrolimus } \\
(\mathrm{n}=39)\end{array}$ & $\begin{array}{l}\text { Cyclosporine } \\
(\mathrm{n}=13)\end{array}$ \\
\hline $\begin{array}{l}\text { Total Immunosuppressant Daily Dose } \\
\text { Decrease }\end{array}$ & $19(36.5 \%)$ & $16(41 \%)$ & $3(23.1 \%)$ \\
Equivalent & $18(34.6 \%)$ & $14(35.9 \%)$ & $4(30.8 \%)$ \\
Increase & $15(28.9 \%)$ & $9(23.1 \%)$ & $6(46.2 \%)$ \\
Total Immunosuppressant Daily Dose/Weight $(\mathrm{kg})$ & $29(74.36 \%)$ & $5(38.46 \%)$ \\
Decrease & $34(65.38 \%)$ & $1(2.56 \%)$ & $1(7.69 \%)$ \\
$\begin{array}{l}\text { Equivalent } \\
\text { Increase }\end{array}$ & $2(3.85 \%)$ & $9(23.08 \%)$ & $7(53.85 \%)$ \\
Immunosuppressant Serum Level & $16(30.77 \%)$ & $31(79.49 \%)$ & $4(30.77 \%)$ \\
Decrease & $35(67.31 \%)$ & $0(0 \%)$ & $0(0 \%)$ \\
Equivalent & $0(0 \%)$ & $8(20.51 \%)$ & $9(69.23 \%)$ \\
Increase & $17(32.69 \%)$ & & \\
\hline
\end{tabular}


Saab S. et al: Curing Hepatitis $C$ affects post liver transplant immunosuppressant use

Table 4. Changes in immunosuppressant parameters before and after achieving a sustained viral response. Data are presented as a median with interquartile range in parenthesis for continuous variables

\begin{tabular}{|c|c|c|c|c|}
\hline Parameter & Before & After & Within patient difference & P-value \\
\hline \multicolumn{5}{|l|}{ Tacrolimus } \\
\hline TAC TDD (mg) & $2(1.5,4)$ & $2.167(1.583,3.75)$ & $0(-0.667,0)$ & 0.174 \\
\hline $\begin{array}{l}\text { TAC TDD } \\
(\mathrm{mg}) / \text { Weight }(\mathrm{kg})\end{array}$ & $0.03(0.019,0.049)$ & $0.029(0.019,0.045)$ & $-0.002(-0.009,0)$ & 0.011 \\
\hline $\begin{array}{l}\text { GFR } \times \text { TAC } \\
\left(\mathrm{mL} / \mathrm{min} / 1.73 \mathrm{~m}^{2} \times \mathrm{mg}\right)\end{array}$ & $507.5(362.285,615.85)$ & $348(216.185,458.5)$ & $-147.57(-281.65,-103.235)$ & $<0.001$ \\
\hline $\begin{array}{l}\text { FK Serum Level } \\
(\mathrm{ng} / \mathrm{mL})\end{array}$ & $8.1(6.57,9.1)$ & $5.13(3.965,6.685)$ & $-2.4(-4.27,-1.25)$ & $<0.001$ \\
\hline \multicolumn{5}{|l|}{ Cyclosporine } \\
\hline CSA TDD $(\mathrm{mg})$ & $150(133.333,200)$ & $166.667(133.333,200)$ & $0(0,25)$ & 0.905 \\
\hline $\begin{array}{l}\text { CSA TDD } \\
(\mathrm{mg}) / \text { Weight }(\mathrm{kg})\end{array}$ & $1.935(1.368,2.813)$ & $2.1(1.531,2.841)$ & $0.153(-0.063,0.302)$ & 0.505 \\
\hline $\begin{array}{l}\text { CSA Serum Level } \\
(\mathrm{ng} / \mathrm{mL})\end{array}$ & $112(79,128.67)$ & $105.67(77,128.33)$ & $5.76(-15.34,15)$ & 0.78 \\
\hline $\begin{array}{l}\text { GFR } \times \text { CSA } \\
\left(\mathrm{mL} / \mathrm{min} / 1.73 \mathrm{~m}^{2} \times \mathrm{mg}\right.\end{array}$ & $6286.67(5059,6720.6)$ & $\begin{array}{l}5563.33(5271, \\
6638.83)\end{array}$ & $212(-1513.66,815.66)$ & 0.944 \\
\hline
\end{tabular}

Abbreviations: TAC, tacrolimus; CSA, cyclosporine; GFR, glomerular filtration rate; TDD, total daily dose.

immunity in LT recipients. Hence, the immunosuppressants may need to be increased accordingly, following the treatment HCV infection.

There are a number of important limitations to our study. First, the study is retrospective, and laboratory test results were not collected using a systematic approach. Nevertheless, this is one of the largest analyses performed on HCV therapy among LT recipients that is applicable and generalizable across
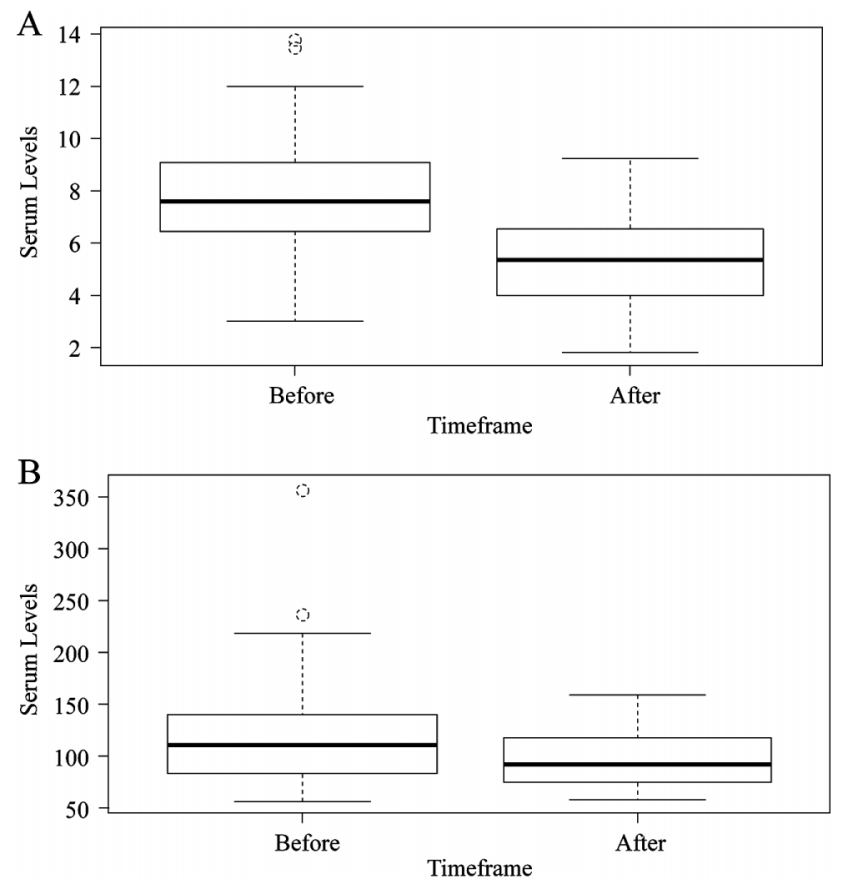

Fig. 1. Tacrolimus (A) and cyclosporine (B) serum levels before and after achieving a sustained viral response. several different antiviral regimens. A prospective trial with different antiviral regimens and a systematic laboratory collection would be helpful to clarify this intricate relationship between HCV therapy and immunosuppression. Second, there is no ideal method to estimate immunosuppressant needs. Dosing of TAC and cyclosporine is not standardized and is adjusted based on multiple factors, including renal function, BMI, and individual provider judgment. We chose several novel parameters (total daily dose of the immunosuppressant, the dose of immunosuppressant per the recipient body weight, and product of immunosuppressant and GFR) to estimate immunosuppressant needs in our study. Nonetheless, the results were consistent across all the measured and calculated parameters.

In our study, curing HCV infection in LT recipients resulted in greater immunosuppression needs. Given the availability, tolerability, and success of all-oral interferon-free antiviral regimens, practitioners should be aware of this potential, unanticipated side effect to prevent graft loss. They may consider more frequent and closer monitoring of immunosuppression levels 12 weeks after SVR.

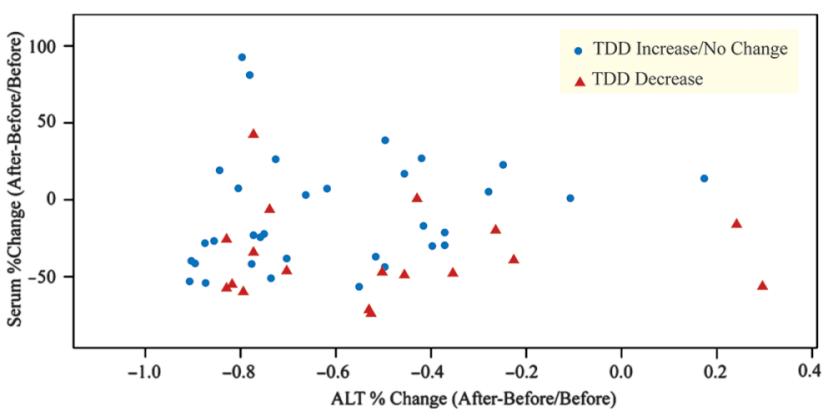

Fig. 2. Alanine transferase (ALT), serum, and total daily dose (TDD) of immunosuppression for both immunosuppressant medications. 
Saab S. et al: Curing Hepatitis $C$ affects post liver transplant immunosuppressant use

\section{Conflict of interest}

None

\section{Author contributions}

Generated the study concept and design, performed data analysis and interpretation, and drafted the manuscript (SS, $J R$ ), contributed to data acquisition (JR, MJ, AF, NJ, SB), critically revised the manuscript for important intellectual content (SS, GC, FD, MEK, SH, RWB), performed statistical analysis (JG, DE), provided administrative support (MJ), supervised the study (SS).

\section{References}

[1] Mazzaferro V, Regalia E, Doci R, Andreola S, Pulvirenti A, Bozzetti F, et al. Liver transplantation for the treatment of small hepatocellular carcinomas in patients with cirrhosis. N Engl J Med 1996;334:693-699. doi: 10.1056/ NEJM199603143341104.

[2] Rubin A, Aguilera V, Berenguer M. Liver transplantation and hepatitis C. Clin Res Hepatol Gastroenterol 2011;35:805-812. doi: 10.1016/j.clinre.2011. 04.009.

[3] Martin P, DiMartini A, Feng S, Brown R Jr, Fallon M. Evaluation for liver transplantation in adults: 2013 practice guideline by the American Association for the Study of Liver Diseases and the American Society of Transplantation. Hepatology 2014;59:1144. doi: 10.1002/hep.26972.

[4] Starzl TE, Koep LJ, Halgrimson CG, Hood J, Schroter GP, Porter KA, Weil R, 3rd. Fifteen years of clinical liver transplantation. Gastroenterology 1979;77: 375-388.

[5] Starzl TE, Iwatsuki S, Van Thiel DH, Gartner JC, Zitelli BJ, Malatack Jj, et al. Evolution of liver transplantation. Hepatology 1982;2:614-636. doi: 10.1002/hep.1840020516.

[6] Calne RY, Williams R. Orthotopic liver transplantation: The first 60 patients. Br Med J 1977;1:471-476. doi: 10.1136/bmj.1.6059.471.

[7] Watt KD, Pedersen RA, Kremers WK, Heimbach JK, Charlton MR. Evolution of causes and risk factors for mortality post-liver transplant: results of the NIDDK longterm follow-up study. Am J Transplant 2010;10:1420-1427. doi: $10.1111 / j .1600-6143.2010 .03126 . x$

[8] Textor SC, Taler SJ, Canzanello VJ, Schwartz L, Augustine JE. Posttransplantation hypertension related to calcineurin inhibitors. Liver Transpl 2000;6: 521-530. doi: 10.1053/jits.2000.9737.

[9] Laryea M, Watt KD, Molinari M, Walsh MJ, McAlister VC, Marotta PJ, et al. Metabolic syndrome in liver transplant recipients: prevalence and association with major vascular events. Liver Transpl 2007;13:1109-1114. doi: 10.1002/ It. 21126 .

[10] Chen T, Jia H, Li J, Chen X, Zhou H, Tian H. New onset diabetes mellitus after liver transplantation and hepatitis $C$ virus infection: meta-analysis of clinical studies. Transpl Int 2009;22:408-415. doi: 10.1111/j.1432-2277.2008. 00804.x.

[11] Kuo HT, Sampaio MS, Ye X, Reddy P, Martin P, Bunnapradist S. Risk factors for new-onset diabetes mellitus in adult liver transplant recipients, an analysis of the Organ Procurement and Transplant Network/ United Network for Organ Sharing database. Transplantation 2010;89:1134-1140. doi: 10.1097/TP. 0b013e3181d2fec1.

[12] Gonwa TA, Mai ML, Melton LB, Hays SR, Goldstein RM, Levy MF, Klintmalm GB. End-stage renal disease (ESRD) after orthotopic liver transplantation (OLTX) using calcineurin-based immunotherapy: risk of development and treatment. Transplantation 2001;72:1934-1939. doi: 10.1097/00007890200112270-00012.

[13] Paramesh AS, Roayaie S, Doan Y, Schwartz ME, Emre S, Fishbein T, et al. Post-liver transplant acute renal failure: factors predicting development of end-stage renal disease. Clin Transplant 2004;18:94-99. doi: 10.1046/j. 1399-0012.2003.00132.x.

[14] Berenguer $M$. Hot topic in hepatitis $C$ virus research: the type of immunosuppression does not matter. Liver Transpl 2011;17:S24-28. doi: 10.1002/It. 22347.

[15] Kim WR, Lake JR, Smith JM, Skeans MA, Schladt DP, Edwards EB, et al. OPTN/SRTR 2013 annual data report: liver. Am J Transplant 2015;15:1-28. doi: 10.1111 /ajt.13197.

[16] Ghobrial RM, Steadman R, Gornbein J, Lassman C, Holt CD, Chen P, et al. A 10-year experience of liver transplantation for hepatitis C: analysis of factors determining outcome in over 500 patients. Ann Surg 2001;234: 384-393. doi: 10.1097/00000658-200109000-00012.
[17] Crespo G, Marino Z, Navasa M, Forns X. Viral hepatitis in liver transplantation. Gastroenterology 2012;142:1373-1383. doi: 10.1053/j.gastro. 2012. 02.011.

[18] Berenguer M, Prieto M, Rayón JM, Mora J, Pastor M, Ortiz V, et al. Natural history of clinically compensated hepatitis $C$ virus-related graft cirrhosis after liver transplantation. Hepatology 2000;32:852-858. doi: 10.1053/jhep. 2000.17924.

[19] Berenguer M, Palau A, Aguilera V, Rayón JM, Juan FS, Prieto M. Clinical benefits of antiviral therapy in patients with recurrent hepatitis $C$ following liver transplantation. Am J Transplant 2008;8:679-687. doi: 10.1111/j.16006143.2007.02126.x.

[20] Carrión JA, Navasa M, García-Retortillo M, García-Pagan JC, Crespo G, Bruguera $M$, et al. Efficacy of antiviral therapy on hepatitis $C$ recurrence after liver transplantation: a randomized controlled study. Gastroenterology 2007;132:1746-1756. doi: 10.1053/j.gastro.2007.03.041.

[21] Saab S, Kalmaz D, Gajjar NA, Hiatt J, Durazo F, Han S, et al. Outcomes of acute rejection after interferon therapy in liver transplant recipients. Liver Transpl 2004;10:859-867. doi: 10.1002/It.20157.

[22] Selzner N, Guindi M, Renner EL, Berenguer M. Immune-mediated complications of the graft in interferon-treated hepatitis $C$ positive liver transplant recipients. J Hepatol 2011;55:207-217. doi: 10.1016/j.jhep.2010. 11.012.

[23] Levitsky J, Fiel MI, Norvell JP, Wang E, Watt KD, Curry MP, et al. Risk for immune-mediated graft dysfunction in liver transplant recipients with recurrent $\mathrm{HCV}$ infection treated with pegylated interferon. Gastroenterology 2012;142:1132-1139. doi: 10.1053/j.gastro.2012.01.030.

[24] Saab S, Jimenez M, Bau S, Goo T, Zhao D, Durazo F, et al. Treating fibrosing cholestatic hepatitis $C$ with sofosbuvir and ribavirin: a matched analysis. Clin Transplant 2015;29:813-819. doi: 10.1111/ctr.12584.

[25] Saab S, Greenberg A, Li E, Bau SN, Durazo F, El-Kabany M, et al. Sofosbuvir and simeprevir is effective for recurrent hepatitis $C$ in liver transplant recipients. Liver Int 2015;35:2442-2447. doi: 10.1111/liv.12856.

[26] Kwo PY, Mantry PS, Coakley E, Te HS, Vargas HE, Brown R Jr, et al. An interferon-free antiviral regimen for HCV after liver transplantation. N Engl J Med 2014;371:2375-2382. doi: 10.1056/NEJMoa1408921.

[27] Charlton M, Everson GT, Flamm SL, Kumar P, Landis C, Brown RS, et al. SOLAR-1 Investigators. Ledipasvir and Sofosbuvir Plus Ribavirin for Treatment of HCV Infection in Patients With Advanced Liver Disease. Gastroenterology 2015;149:649-659. doi: 10.1053/j.gastro.2015.05.010.

[28] Moini M, Schilsky ML, Tichy EM. Review on immunosuppression in liver transplantation. World J Hepatol 2015;7:1355-1368. doi: 10.4254/wjh.v7.i10. 1355.

[29] Lan X, Liu MG, Chen HX, Liu HM, Zeng W, Wei D, Chen P. Efficacy of immunosuppression monotherapy after liver transplantation: a meta-analysis. World J Gastroenterol 2014;20:12330-12340. doi: 10.3748/wjg.v20.i34. 12330.

[30] Manzia TM, Angelico R, Ciano P, Mugweru J, Owusu K, Sforza D, et al. Impact of immunosuppression minimization and withdrawal in long-term hepatitis C virus liver transplant recipients. World J Gastroenterol 2014;20:1221712225. doi: $10.3748 /$ wjg.v20.i34.12217.

[31] Londoño MC, Rimola A, O'Grady J, Sanchez-Fueyo A. Immunosuppression minimization vs. complete drug withdrawal in liver transplantation. J Hepatol 2013;59:872-879. doi: 10.1016/j.jhep.2013.04.003.

[32] Liu Z, Chen Y, Tao R, Xv J, Meng J, Yong X. Tacrolimus-based versus cyclosporine-based immunosuppression in hepatitis $C$ virus-infected patients after liver transplantation: a meta-analysis and systematic review. PLoS One 2014;9: e107057. doi: 10.1371/journal.pone.0107057.

[33] Badri P, Dutta S, Coakley E, Cohen D, Ding B, Podsadecki T, et al. Pharmacokinetics and dose recommendations for cyclosporine and tacrolimus when coadministered with ABT-450, ombitasvir, and dasabuvir. Am J Transplant 2015;15:1313-1322. doi: 10.1111/ajt.13111.

[34] Reddy KR, Everson G, Flamm S., Denning J, Arterburn S, Brandt-Sarif T, et al. Ledipasvir/Sofosbuvir with Ribavirin for the Treatment of HCV in Patients with Post Transplant Recurrence: Preliminary Results of a Prospective, Multicenter Study. Hepatology 2014;60:200A.

[35] Charlton M, Gane E, Manns MP, Brown RS Jr, Curry MP, Kwo PY, et al. Sofosbuvir and ribavirin for treatment of compensated recurrent hepatitis $C$ virus infection after liver transplantation. Gastroenterology 2015;148:108-117. doi: 10.1053/j.gastro.2014.10.001.

[36] Niwa T, Yamamoto S, Saito M, Shiraga T, Takagi A. Effect of cyclosporine and tacrolimus on cytochrome p450 activities in human liver microsomes. Yakugaku Zasshi 2007;127:209-216. doi: 10.1248/yakushi.127.209.

[37] Bengsch B, Seigel B, Ruhl M, Timm J, Kuntz M, Blum HE, et al. Coexpression of PD-1, 2B4, CD160, and KLRG1 on exhausted HCV-specific CD8+ T cells is linked to antigen recognition and T cell differentiation. PLoS Pathog 2010;6: e1000947. doi: 10.1371/journal.ppat.1000947.

[38] Klenerman P, Thimme R. T cell responses in hepatitis $C$ : the good, the bad and the unconventional. Gut 2012;61:1226-1234. doi: $10.1136 /$ gutjnl2011-300620. 
Saab S. et al: Curing Hepatitis $C$ affects post liver transplant immunosuppressant use

[39] Abdel-Hakeem MS, Bédard N, Badr G, Ostrowski M, Sékaly RP, Bruneau J, et al. Comparison of immune restoration in early vs. late alpha interferon therapy against hepatitis C virus. J Virol 2010;84:10429-10435. doi: 10. 1128/JVI.01094-10.

[40] Badr G, Bédard N, Abdel-Hakeem MS, Trautmann L, Willems B, Villeneuve J-P, et al. Early interferon therapy for hepatitis $C$ virus infection rescues polyfunctional, long-lived CD8+ memory T cells. J Virol 2008;82:1001710031. doi: $10.1128 / \mathrm{JVI} .01083-08$.

[41] Bohne F, Londoño MC, Benítez C, Miquel R, Martínez-Llordella M, Russo C, et al. HCV-induced immune responses influence the development of operational tolerance after liver transplantation in humans. Sci TransI Med 2014;6: 242ra81. doi: 10.1126/scitransImed.3008793. 